\title{
鋼索用素線の疲労破断面について*
}

\author{
上田 和 彦 $^{1}$ 藤 中 雄 三 $^{2}$
}

[UDC 677.72]

\section{Fatigue Fractured Surface of Component Wire for Steel Wire Ropes}

by Kazuhiko UEDA ${ }^{1}$ and Yuzo FUJINAKA ${ }^{2}$

Fatigue on component wire for steel wire ropes under tension and bending has been studied. This paper describes the result of fatigue test of a steel wire which bears a natural curling and discusses the result of observation of the fracture face on specimen. Relation between S-N diagram and the fracture face is also discussed.

The following items show the conclusion.

(1) The degree of symmetry of fracture faces depend on both the residual stress and the curvature which the specimen beared before installed.

(2) Degree of flatness on the fatigue fracture face and the shape of S-N diagram are considerably influenced by the number of crack initiation spots.

(3) In the case installed convexly upwards with single spot initiation, the greater tensile load permit larger areas of the rapid fracture regions.

KEY WORDS: Fatigue Fractured Surface, Tension and Bending, Residual Stress, Curvature, Number of Crack Initiation Spots, Area of Rapid Fracture Region

(1. Assoc. Prof, Maizuru College of Technology.

2. Prof., Dr., Faculty of Engineering, Kyoto University.

\section{1. 緒}

動索として用いられ，滑車によって綝返し曲げを受ける鋼索を 構成する素線の疲労を研究する一環として，さきにまず鋼索用素 線の引張曲げ疲労試験機を製作してそれによる研究結果の一部を 報告した ${ }^{1) 〜 3) 。 ~}$

本研究はそれに引続いて, 素線に生ずる応力と破断面の観点か ら素線の疲労破壊現象を解明するために，今までと同様に反りを もつ試料を使って引張片振り曲げ疲労試験を行い, 反りによる影 響とき裂発生点の数を考虑して, S-N 線図の形と破断面の形態と の関係とともに疲労破断面の平滑さの程度等についての検討を行 った。ここでSは設置した素線の下側表面に生ずる最大応力で, Nは破断までの繰返し数を示す。このように反りによる影響とき 裂発生点の数を考慮して実験結果の検討を行っているのが本研究 の特色であると考える。

\section{2. 実験装置および実験方法}

\section{$2 \cdot 1$ 試料}

供試材は直径が異なる 3 種類の鋼索用硬鋼線で直径 $2.5 \mathrm{~mm}$ また

* 1989 年 5 月 12 日受付 9 月 27 日受理 昭和 62 年 9 月 19 日, 資 源・素材関係学協会合同秋季大会にて一部発表

1. 正会員 舞鶴工業高等専門学校助教授 機械工学科

2. 正会員 工博 京都大学教授 工学部資源工学科

キーワード : 疲労破断面, 引張曲げ, 残留応力, 曲率, き裂発生箇所の 数, 急速破断部の面積
Table 1 Outline of specimen.

\begin{tabular}{l|l|l|l}
\hline & \multicolumn{1}{|c|}{ I } & \multicolumn{1}{c}{ II } & \multicolumn{1}{c}{ III } \\
\hline Diameter & $0.82 \mathrm{~mm}$ & $1.25 \mathrm{~mm}$ & $1.17 \mathrm{~mm}$ \\
C content & $0.62 \%$ & $0.63 \%$ & $0.61 \%$ \\
Mn content & $0.70 \%$ & - & $0.42 \%$ \\
Tensile strength & $179 \mathrm{kgf} / \mathrm{mm}^{2}$ & $205 \mathrm{kgf} / \mathrm{mm}^{2}$ & $178 \mathrm{kgf} / \mathrm{mm}^{2}$ \\
Dia. of wire rod & $2.5 \mathrm{~mm}$ & $5.5 \mathrm{~mm}$ & - \\
Radius of curvature & $140 \sim$ & $230 \sim$ & $1000 \sim$ \\
& $160 \mathrm{~mm}$ & $240 \mathrm{~mm}$ & $1400 \mathrm{~mm}$ \\
Length & $365 \mathrm{~mm}$ & $480 \mathrm{~mm}$ & $480 \mathrm{~mm}$ \\
Effective length & $200 \mathrm{~mm}$ & $200 \mathrm{~mm}$ & $200 \mathrm{~mm}$ \\
\hline
\end{tabular}

は $5.5 \mathrm{~mm}$ の母線から線引きされたものであり, その概要は表 1 に 示すとおりである。

\section{$2 \cdot 2$ 実験装置}

図 1 は実験装置で, 三相誘導電動機から Vベルトと 2 段のプー リーを経て約 $300 \mathrm{rpm}$ でクランクを駆動しクランクアームを介し て, 素線に両振りまたは片振りの繰返し曲げを与えている。ロー ドセルによる測定の結果, 実験中の引張荷重 $12 \sim 80 \mathrm{kgf}$ 対 して張力の変動量は $1 \mathrm{kgf}$ 以内で, 素線と装置各部の伸びによる 引張応力の変動は小さく, 塑性変形が無視できるものとみられる。 試料の両端はチャックを介して下方のばねによる引張力が与えら れ, その途中に荷重測定用のロードセルと試料破断時の自動停止 装置が設けられている。繰返しの積算回数はフォトインタラプタ 


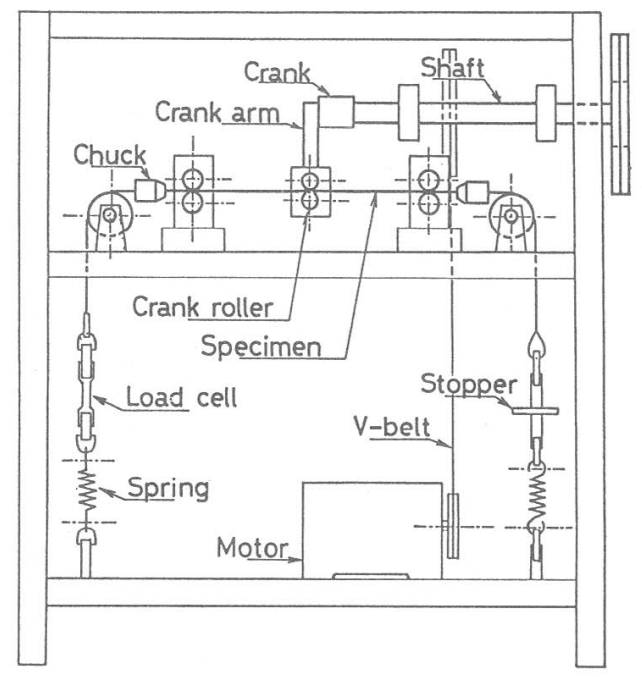

Fig. 1 Fatigue testing equipment for steel wire under both tension and bending.

を使った計数装置を用いてディジタル表示される。チャックは, すべりを生じずかつ質量の小さい構造とするために，3つ爪式コ レット型のものを用いる。

\section{$2 \cdot 3$ 実験方法}

図1のように試料の素線の両端をそれぞれチャックによってつ かみ，そのチャックを通じて有効長さが $200 \mathrm{~mm}$ の素線に引張荷 重を与える。その大きさは直径が $0.82 \mathrm{~mm}$ の試料では $12 \sim 40 \mathrm{kgf}$, 直径が $1.17 \mathrm{~mm}$ と $1.25 \mathrm{~mm}$ 試料では $40 \sim 80 \mathrm{~kg}$ とする。実験装置 を運転すると所定のたわみ量（両振り式では土 $3.5 \sim \pm 7 \mathrm{~mm}$, 片振り式では $7 \mathrm{~mm}$ と $8.5 \mathrm{~mm}$ ) がクランクによる押し下げないし 押し上げ（片振り式では押し下げのみ）によって与えられる。

\section{3. 素線に生ずる応力}

素線を上に凸または下に凸となるように設置した場合，その上 側表面または下側表面（以下単に「上面」または「下面」と称す） に存在する長手方向の残留応力, 反りの戻り応力, 引張応力掠よ び曲げ応力をそれぞれ $\sigma_{r}, \sigma_{c}, \sigma_{t}$ および $\sigma_{b}$ とする。ここで残留 応力 $\sigma_{r}$ は, 自然状態に放置されたとき上に凸の素線の上面に存在 する応力のことで, 製造の過程で生ずる。反りの戻り応力 $\sigma_{c}$ は, 自然状態で反っている試料を両端から引張って真直ぐに戻してい く過程で生ずる応力で, 曲率半径によってその值が決まる。自然 状態での曲率半径が $r_{N}$ である素線を引張って, 曲率半径が $r$ にな ったときの反りの戻り応力 $\sigma_{c}$ は $\sigma_{c}=E y\left(1 / r_{N}-1 / r\right)$ となる。ここ で $E$ は素線の縦弾性係数で $y$ は素線の半径を示す。したがって自 然状態 $\left(r=r_{N}\right)$ における反りの戻り応力は 0 で, 素線を強く引張 ったときのそれはほぼ $E y / r_{N}$ となる。曲げ応力 $\sigma_{b}$ は, 試料中央 部を押込んで曲げることにより生ずる垂直応力で, 押込み量によ って変動し 1 周期中の応力振幅は図 2 と図 3 に示すと㧍りである。 外力が加わらないときは上に凸の素線の上側に+ $\sigma_{r}$, また下面に - $\sigma_{r}$ の残留応力が存在するので, 下に凸の素線であればその上面 にー $\sigma_{r}$ そして下面には $+\sigma_{r}$ の残留応力が存在する ${ }^{1)}$ 。ここでは符 号の十は引張を, 一は圧縮を示す。引張片振り曲げと引張両振り 曲げによる素線 上の上端と下端の応力変動の状況, 特に本稿で重 要な働きをしている残留応力と反りの戻り応力の影響を具体的に 図でホすと，図 $2^{2)}$ と図 $3^{3)}$ のように表される。

\section{4. 実験結果および考察}

\section{$4 \cdot 1$ 引張両振り曲げ疲労試験結果}
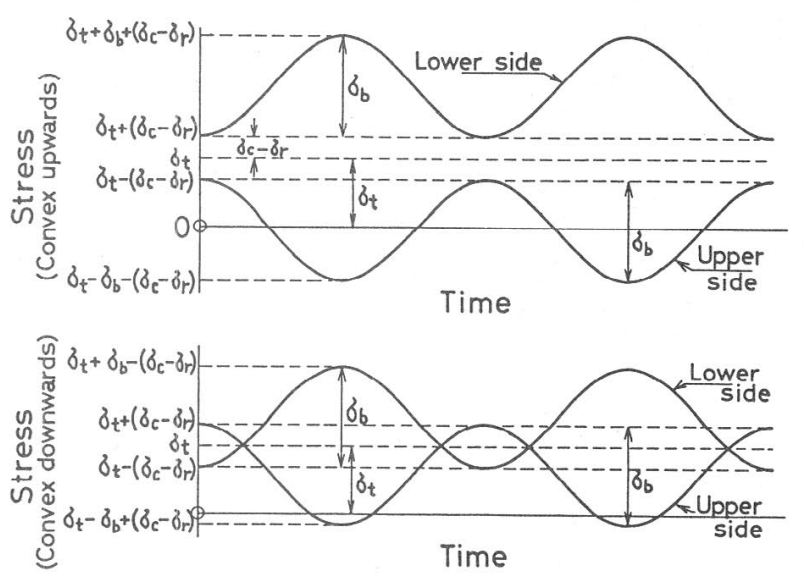

Fig. 2 Stress on component steel wire under tension and pulsating bending.

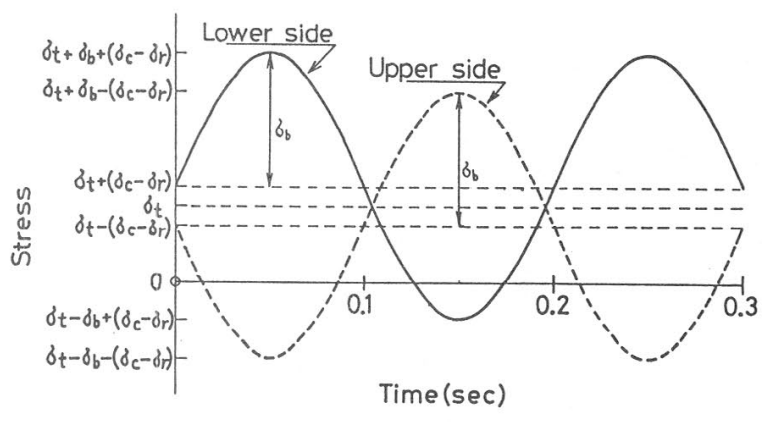

Fig. 3 Stress on component steel wire installed convexly upwards under tension and alternating bending.

本報記載の写真はすべて走査電子顕微鏡によるもので，直径が $0.82 \mathrm{~mm}$ の試料の場合, 観察したほとんどすべての破面は図 4 に 示すように上下対称に近い典型的な両振り破面を示していた。こ の場合は $\sigma_{c} \cong \sigma_{r}$ の関係から, 図 3 に示すように素線の上面と下 面に交互に最大応力を生じ, ほぼ同時に上下両面から中心軸に向 ってき裂が進行して最後に中央部で急速破断するようである。

直径が $1.25 \mathrm{~mm}$ の試料の場合には, 両振りであっても観察した ほとんどすべての破而は図 5 に示すように極端な上下非対称性を 示していた。これは直径が $1.25 \mathrm{~mm}$ のときは, 直径が $0.82 \mathrm{~mm}$ の 試料との破面の明確な違いから, 試料の上面と下面の最大応力の 差 $\left\{2\left(\sigma_{0}-\sigma_{r}\right)\right\}$ が 0 ではなくて $30 \sim 35 \mathrm{kgf} / \mathrm{mm}^{2}$ の值をもち, 最 大応力の大きい側からき裂が先に進展して上下の一方に片寄った ものと考えられる。

実用上の素線では, 最大応力が小さくなる関係上両者の応力差 がほぼ0に近い両振り破断面が表れた方がよい。反りの戻り応 力 $\sigma_{c}$ は前述のように引張荷重によって決まるが, ある程度以上の

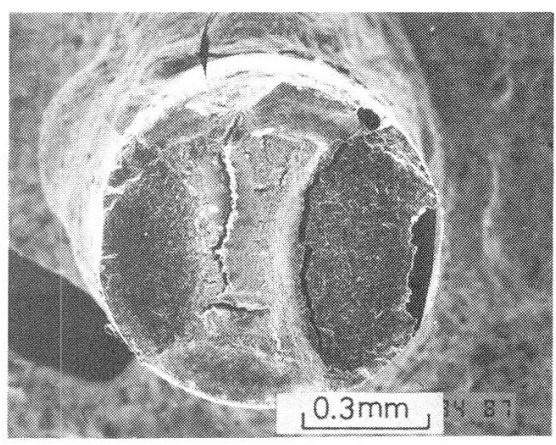

Fig. 4 Fracture face resulted from tension and alternating bending. ( $\phi 0.82$, Symmetry) 


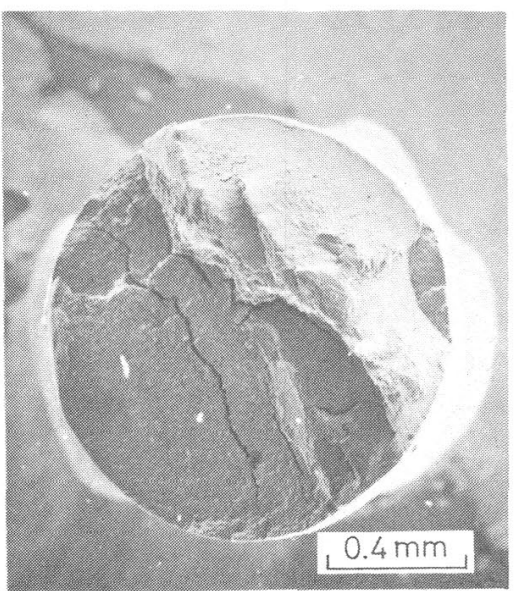

Fig. 5 Fracture face resulted from tension and alternating bending. $(\phi 1.25$, Unsymmetry)

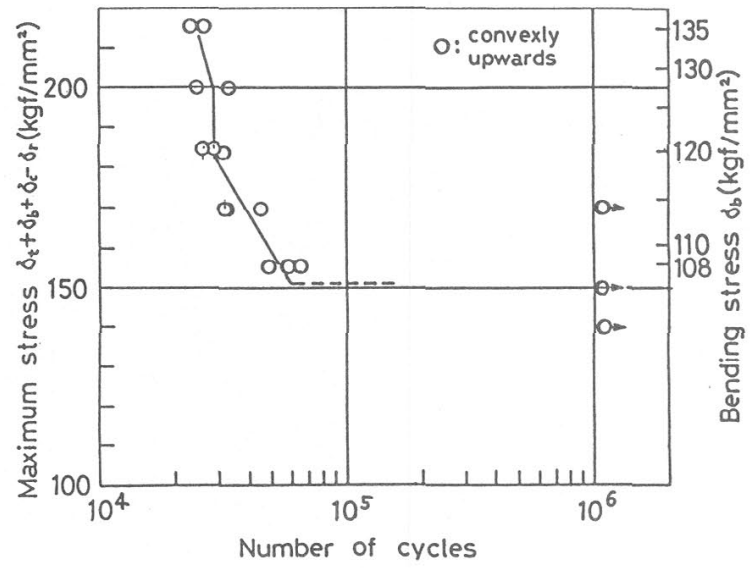

Fig. 6 S-N diagram of a wire of diameter $1.25 \mathrm{~mm}$ installed convexly upwards under tension and pulsating bending obtained by depressions of $7 \mathrm{~mm}$. (Maximum stress is the value after correction.)

荷重をかければほぼ一定となり, 残留応力 $\sigma_{r}$ も使用中ではほぼ一 定とみられるので，使い方によって良好な破断面が現れるように するのは難しいと考えられる。

\section{$4 \cdot 2$ 引張片振り曲げ疲労試験結果}

引張片振り曲げ疲労試験結果として, 押込み深さが同じで上に凸 と下に凸に設定した素線についてそれぞれ $S-\mathrm{N}$ 線図を描いて，両 線図の疲労限度がほぼ同じになるように $\Delta \sigma=2\left(\sigma_{c}-\sigma_{r}\right)$ の值を決 めて最大応力の補正を行うが, ${ }^{1)}$ 図6 と図7 亿その一例を示す。上 に凸に設定した直径が $1.17 \mathrm{~mm}$ の試料の $\mathrm{S}-\mathrm{N}$ 線図として図 8 に示 す。引張片振り疲労破面を図9から図14に示す。

上に凸に設置した場合（以下では「上に凸」と称す）で直径が $1.25 \mathrm{~mm}$ の試料について, 全横断面に占める最終破断部の面積割 合を目測で求めると, 引張荷重が $40 \mathrm{~kg} \mathrm{f} て ゙ 25 \sim 30 \%, 50 \mathrm{kgf}$ 〜 50\%, $60 \mathrm{kgf}$ で $45 \sim 70 \%, 70 \mathrm{kgf}$ で $40 \sim 50 \%, 80 \mathrm{kgf}$ で $45 \sim$ $50 \%$ (場合により $70 \%$ ) となっている。引張荷重が $60 \mathrm{~kg}$ f 位まで は, あまり明確ではないが荷重が増加するにつれて，横断面にお ける最終破断部の面積割合は増加している。一般に疲労によるき 裂が進展して素線の断面積が減少し, 最後に応力に耐えきれなく なって破断する。この場合, 押込み荷重による曲げ応力の増加は 疲労寿命に影響を与えるとともに破断の引き金の作用をし，実験 中常時作用している引張応力が大きいほど大きな未疲労部分が最 後に急速破断するなど，最終破断が主として引張荷重に影響され

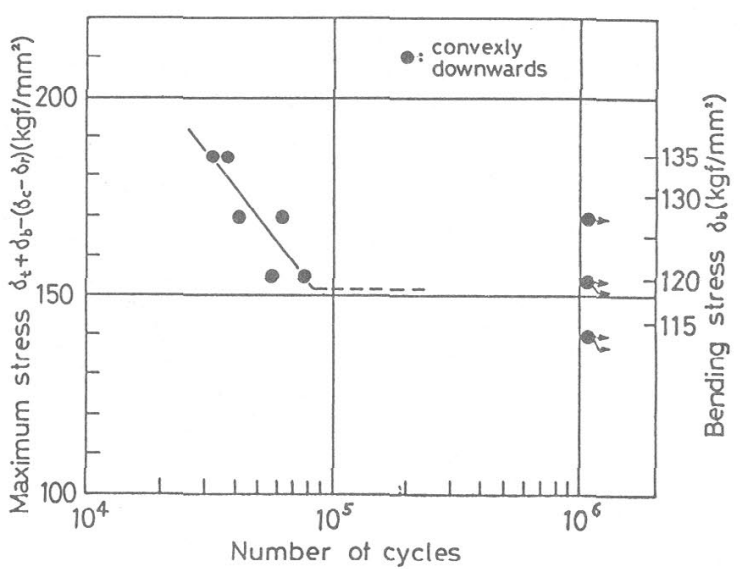

Fig. 7 S-N diagram of a wire of diameter $1.25 \mathrm{~mm}$ installed convexly downwards under tension and pulsating bending obtained by depressions of $7 \mathrm{~mm}$. (Maximum stress is the value after correction.)

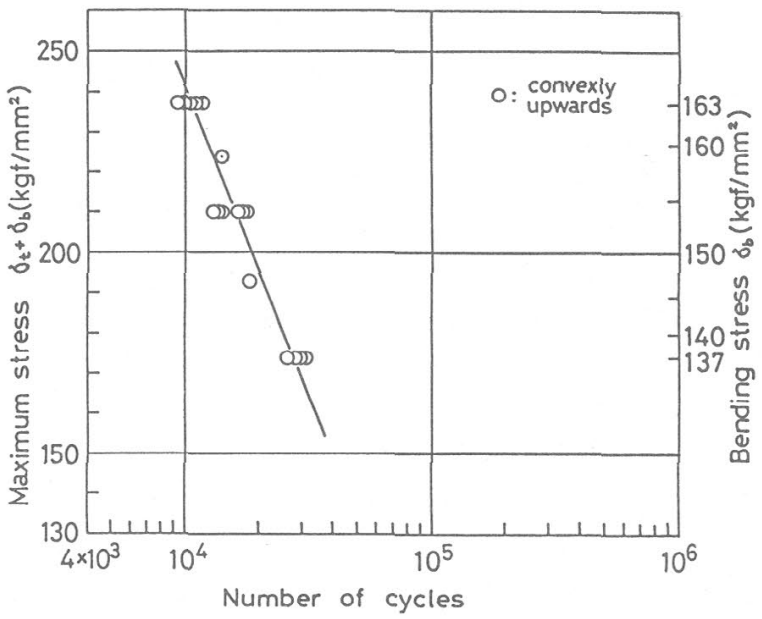

Fig. 8 S-N diagram of a wire of diameter $1.17 \mathrm{~mm}$ installed convexly upwards under tension and pulsating bending obtained by depressions of $8.5 \mathrm{~mm}$. (Maximum stress is the value before correction.)

るために引張荷重と最終破断面の面積割合が比例的になると考光 られる。荷重が $40 \mathrm{kgf} て ゙ は$ 図 9 のように破断部に段付は認められ ないが, 荷重が $60 \mathrm{~kg}$ f以上で大きくなるほど図10 と図 11 のよう にき裂発生点が 2 つの場合が多くなり，疲学破断部が 2 つ以上に 分れた破面となるなど横断面の形態も複雑となる。その理由とし て，引張荷重が大きくなると引張応力とともに押込みによる曲げ 応力も大きくなり, 素線の位置による応力差よりも表面の铛小欠 樎による応力集中の影響が大きくなって，素線の下端から少しず れた複数の微小欠陥からき裂が発生しやすくなるためと考えられ る。図12の破面屺き裂発生点が 2 つの場合の変型と変えられる。 荷重が $40 \sim 60 \mathrm{kgf}$ の範囲では, $S-N$ 線図上のデータがほぼ直線 的に変化して, 最大応力が増加するとともに破断までの繰返し数 が減少しているが, これはほぼき裂発生点が 1 つの場合に対応し ている。

同様にして上に凸で直径が $1.17 \mathrm{~mm}$ の試料について，全横断面 に占める最終破断部の面積割合を目測で求めると,引張何重が 40 $\mathrm{kgf}$ で $30 \sim 40 \%, 60 \mathrm{kgf}$ で $45 \sim 50 \%, 80 \mathrm{kgf}$ で $55 \sim 60 \%$ とな っていて, 引張荷重とともに増大している。この場合, 疲労破断 の後半といらか最後にしばしば大きなき裂が認められるが, 疲労 


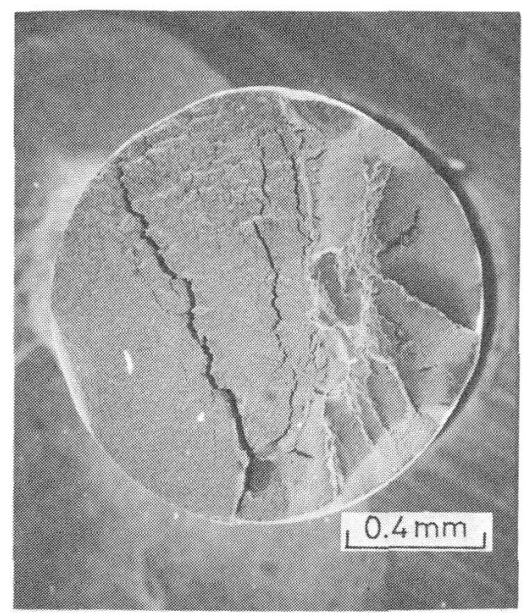

Fig. 9 Fracture face resulted from tension and pulsating bending. ( $\phi 1.25$, Convexly upwards, Tensile load: $40 \mathrm{kgf}$ )

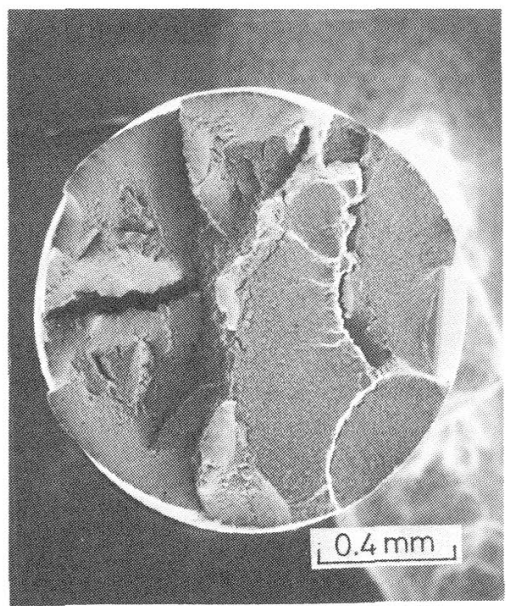

Fig. 12 Fracture face resulted from tension and pulsating bending. ( $\phi 1.25$, Convexly upwards, Tensile load: $80 \mathrm{kgf}$ )

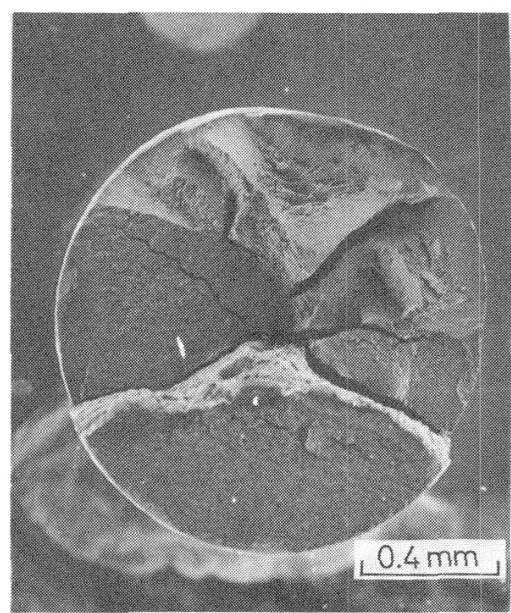

Fig. 10 Fracture face resulted from tension and pulsating bending. ( $\phi 1.25$, Convexly upwards, Tensile load: $70 \mathrm{kgf}$ )

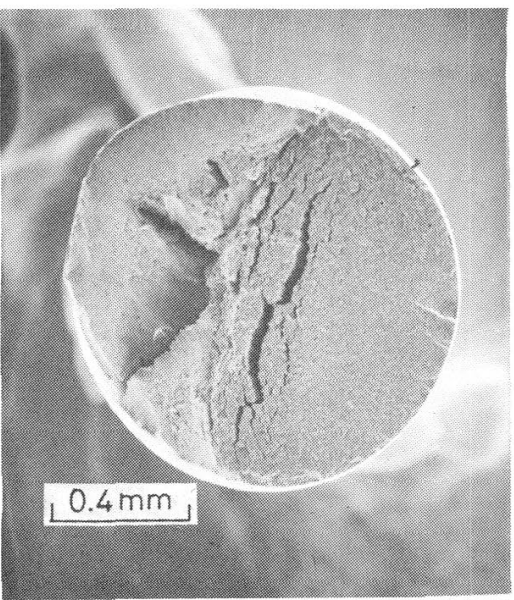

Fig. 13 Fracture face resulted from tension and pulsating bending. ( $\phi 1.17$, Convexly upwards, Tensile load: $60 \mathrm{kgf}$ )

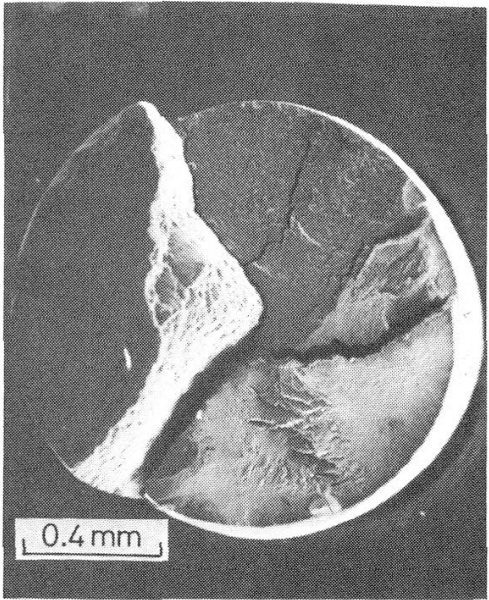

Fig. 11 Fracture face resulted from tension and pulsating bending. ( $\phi 1.25$, Convexly upwards, Tensile load: $80 \mathrm{kgf}$ )

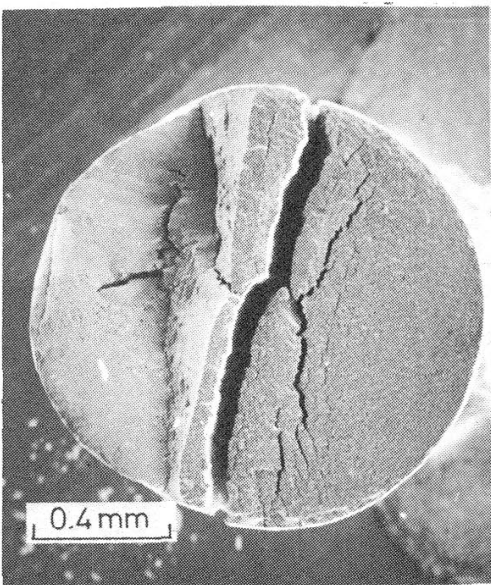

Fig. 14 Fracture face resulted from tension and pulsating bending. ( $\phi 1.25$, Convexly downwards, Tensile load: $80 \mathrm{kgf}$ )
破面はほぼ平面である。荷重が $40 \sim 80 \mathrm{kgf}$ 全範囲にわたって, き裂の発生点は 1 つで $\mathrm{S}-\mathrm{N}$ 線図上のデータがほぼ直線的に変化 している。

直径が $1.25 \mathrm{~mm}$ の試料と比べて直径が $1.17 \mathrm{~mm}$ の試料の方が粘 りがあり,この違いによって引張荷重が大きい場合に硬くてもろ い材料ほど微小欠陥による応力集中の影響を受けやすいため, 破 断形態の違いが表れたものと考えられる。図13のように疲労破 断部と最終破断部の境界が円孤状になっているのは, 貝殼模様は 認められなくても, き裂が 1 つの発生点からほぼ同心円状に進展 した結果と考えられる。

下に凸に設置した場合 (以下「下に凸」と称す) が直径が 1.25

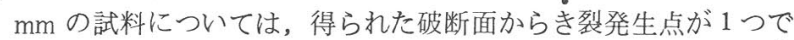
あることを示している。疲労破断部には, 図14のように大きなき 裂が見られる場合はあるが，破面はほぼ均一な平面である。荷重 が 60〜 $80 \mathrm{kgf}$ では, 全横断面に占める最終破断部の割合は 40 〜 50 \%であるが, 最終破断部の面積と引張荷重の間にはほと儿ど相関 関係は認められない。下に円の場合の上うに破断形態が一様な範 囲では, S-N線図は上に凸で荷重が $40 \sim 60 \mathrm{~kg} f$ の場合と同様の
変化をしている。

直径が $1.17 \mathrm{~mm}$ の試料で下に凸の場合は，上に凸の場合に比べ て最大応力が小さく緩い条件での試験となるので, き裂の発生点 は 1 つで疲労破面は平滑である。

\section{$4 \cdot 3$ ミクロおよびマク口破面}

ミク口的には疲労破断部に硬鋼に特有の不規則なき裂がみられ， 疲労特有のストライエーションまたはそれに類する模様は認めら れない。また最終破断部に急速破断面に特有のディンブルが認め られる4)。

引張片振り曲げ疲労によって破断した硬鋼線のマクロ形態は, き裂発生点が 1 つの場合にはほぼ丸棒を軸方向に直角に切断した

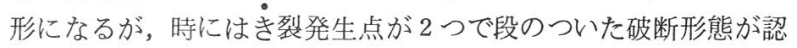
められた。後者の場合, 破断部を模型的に描くと図15のように表 わされ, 試料の長手方向に少し間隔が離れた 2 つのき裂の発生点 CからFのように疲学き裂が別個に進展して, 引張荷重に耐えら れなくなって破断時にR 1 , R 2 の順でき裂が合体したものと考光 られる。前述の図10 と図11の破断面は図 15 (3)の場合に相当し, 実験した範囲では同図(2)の場合は認められなかった。このように 


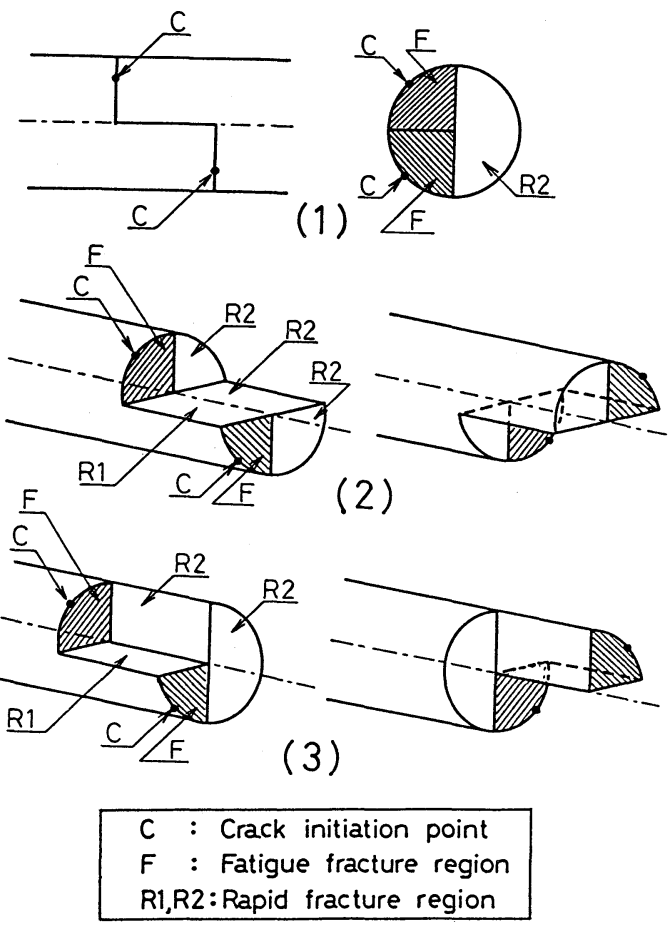

Fig. 15 Model of fracture faces bearing two spots of crack initiation.

き裂は必ずしも上下両面から発生するとは限らないようである。

\section{5. 結言}

いままでに述べた実験と考察の結果, 得られた結論はつぎのと おりである。

1）素線の取付け姿勢を反りの方向と一致させた両振り試験に おいて, 反りの戻り応力と残留応力の差が 0 またはほとんど 0 に
近い場合に典型的な対称形を示す両振り破断面となり, 両者の応 力差が大きいほど破断面の非対称性が大きくなると考元られ，そ の差が例えば $15 \mathrm{kgf} / \mathrm{mm}^{2}$ の場合には著しく非対称な破断面とな る。実用上の素線では, 最大応力が小さくなる関係上両者の応力 差がほぼ 0 に近い両振り破断面が現れた方がよいが, 意図的に そのような使い方をするのは困難である。

2) 片振りの場合, き裂の発生点が 1 つか 2 つかによって疲労 破断部が平滑であるか粗面になるかが決まり, S-N 線図にも違い が表れる。硬くてもろい硬鋼線で引張荷重を大きくした場合に き裂の発生点がこ実験なることが多く, 破断面の形態も複雑とな る。き裂の発生点は 1 つの方が, $\mathrm{S}-\mathrm{N}$ 線図が規則的で疲労寿命が 予測しやすいので良い。実用上で浭鋼線のうちでも特に硬くて もろく引張強さが $200 \mathrm{kgf} / \mathrm{mm}^{2}$ 程度以上の場合, 例えば本実験に おける破断強さの $25 \%$ 程度以下のように, 引張荷重を相当低くお さえて使用するのが望ましいと言える。

3）上に凸になる形で試料を設置して片振り試験を行ったとき, き裂の発生点が 1 つで疲労破断面が平滑である場合に, 引張荷重 の大きさと最終破断部の面積が全横断面に占める割合は比例的で ある。この場合, 最終破断においては引張荷重が主要な働きをし ているので, 最終破断部の面積より稼動中の引張荷重を推定する ことができる。

、おわりに, 本研究に用いた試料の素線を提供していただいた神 鋼鋼線工業(株)ならびに東京製鋼(株)に謝意を表するとともに， 実験装置の製作等にあたってご援助いただいた舞鶴高専機械工学 科の小倉係長をはじめ技官の方々および当時卒研生であった伊庭 道夫, 森本弘毅の両君をはじめとする諸氏に謝意を表する。

\section{参考文 献}

1）上田和彦·藤中雄三：水㺟会誌，20[1]，109 112, (1983)

2）上田和彦・藤中雄三 : 水曜会誌, 20 [3], 223 227, (1984)

3) 藤中雄三。上田和彦: 日本鉱業会誌, 102 [1181], 401 405, (1986)

4）たとえば小寺沢良一：鉄と鋼，70[8]，803～814，（1984） 